\title{
Comparative Analysis between Real Cost and INA- CBG's claims of Service Costs in Chronic Kidney Disease Patients with Hemodialysis
}

\author{
Riqqah Nadhira $^{1^{*}}$, Irwan Saputra ${ }^{1,2}$, Said Usman ${ }^{1,2}$, Bakhtiar $^{3}$, Nurjannah $^{4}$ \\ ${ }^{1}$ Postgraduate program, Faculty of Medicine, Universitas Syiah Kuala, Indonesia \\ ${ }^{2}$ Departement of Community Medicine, Faculty of Medicine, Universitas Syiah Kuala, Banda Aceh, \\ Indonesia \\ ${ }^{3}$ Department of Pediatrics, Faculty of Medicine, Universitas Syiah Kuala, Banda Aceh, Indonesia \\ ${ }^{4}$ Magister of Public Health, Faculty of Medicine, Universitas Syiah Kuala, Banda Aceh, Indonesia \\ * riqqahnadhira@gmail.com
}

\begin{abstract}
Chronic Kidney Disease (CKD) is prevalent among the global population, particularly with people with non-communicable diseases, such as diabetes mellitus, hypertension, and other degenerative diseases. CKD is notably associated with poor prognosis. Indonesia national insurance, called BPJS, has ranked CKD treatment regimens as the second most expensive claim. In fact, there is a discrepancy between hospital tariffs and INA-CBGs claims (listing of claims released by BPJS); thus, several disadvantages to the hospital continuity are inevitable. The study aimed to determine the unit costs of the management for the care of CKD patients with hemodialysis based on real cost (hospital tariffs) and INA-CBGs claims. This study was an observational analytic study conducted in the Hemodialysis unit of Zainal Abidin Hospital (RSUDZA), Banda Aceh, Indonesia. Data collection was carried out by taking secondary data from CKD patient visits in January-December 2019. The study population was all CKD patients in the registry of 2019 in the hospital, with a total of 406 patients enrolled. The highest unit cost of care based on real costs was the cost of surgical procedures, and the cost difference between INA-CBG's and hospital tariffs in the treatment of patients with CKD is significantly different ( $\mathrm{p}$-value $=0.014$, with gap difference of IDR 2,146,086). It is suggested an urgent evaluation and scrutinization for the management of CKD patients with hemodialysis to prevent the different treatment costs in the service.
\end{abstract}

Keywords : INA-CBG's, Real Cost, Chronic Kidney Disease 


\section{STRADA Jurnal Ilmiah Kesehatan}

DOI: $10.30994 /$ sjik.v9i2.372

ISSN: 2252-3847 (print); 2614-350X (online)

Vol.9 No.2 November 2020 Page.726-732

\section{BACKGROUND}

The enactment of UU No. 24 of 2011 concerning BPJS (National Insurance Company) in January 2014 has urged the implementation of the financing system performed following INA-CBGs, which require the government to immediately open service packages for specific cases or diseases among insurance (BPJS). National Health Insurance scheme, so-called JKN (Jaminan Kesehatan Nasional), utilizes INA-CBG's claim method which defined as the payment method that is carried out on known-cost of health service, prior this method capitation and case-based payment (case mix) has been applied for the insurance scheme. INA-CBGS's will use diagnosis stratification and procedure in accordance with clinical characteristics, resource utilization, or treatment cost (Kemenkes RI, 2016; Presiden RI, 2011).

$\mathrm{CKD}$ is a long-life and global public health problem; it gains attention because there was an increase CKD prevalence in the last decades, poor prognosis, and high cost of treatment (Glassock et al., 2017). Global Burden of Disease stated that CKD as the $27^{\text {th }}$ rank cause of death in 1990 , but it increased to $18^{\text {th }}$ rank in 2010. Meanwhile, the whole management of CKD patients was ranked as the second most expensive costrelated treatment (IRR, 2018; PUSDATIN, 2017). Based on the Ministry of Health rules No.812 of 2010 about the Dialysis Services in Health Care Facilities, dialysis is a medical procedure that provides kidney care assistance for optimal health care, consisting of peritoneal dialysis and hemodialysis (RI Ministry of Health, 2010). BPJS Health documents through CNBC Indonesia have recorded treatment cost for chronic kidney disease was about 2.3 trillion in 2018, and the first trimester of 2019 (JanuaryMarch) has noted a rapid increase reaching IDR. 672 million; these trends continue to increase monthly (CNBC INDONESIA, 2019). In 2015, a total of IDR. 2.68 trillion was spent on CKD, both in inpatient and outpatient, an increase from 2014, which was 2.2 trillion rupiahs (PUSDATIN, 2017). Research conducted at Banda Aceh Regional Hospital discovered the total hospital costs incurred for inpatient assistance in the Medical Staff Group was $-30.7 \%$ of the costs required by BPJS (Harnold, S. P., Zulfakar, \& Sovia, C. N., 2017).

In this study, a cost analysis will be carried out to determine the differences and the average costs required for the treatment of CKD patients with hemodialysis based on the INA-CBGs grouping demonstrated from the perspective of the hospital as well as the cost components associated with hospital tariffs for CKD patients with hemodialysis in RSUDZA.

\section{METHOD \\ Study Design}

This was an analytic cross-sectional study. The observation would measure cost variables in the comparison between real costs / hospital tariffs and INA-CBG's claim for the management of $\mathrm{CKD}$ patients with hemodialysis without administering intervention to patients in the Regional Hospital of Zainal Abidin (RSUDZA), Banda Aceh, Indonesia, in January-February 2020.

\section{Data Collection and Patients}

The study population enrolled all chronic kidney disease patients with hemodialysis treated in the Hemodialysis installation of the hospital during a one-year period of 2019. The total sampling technique was applied in the studywith 406 patients visiting the installation regularly. There were several inclusion criteria, such as inpatient CKD 


\section{STRADA Jurnal Ilmiah Kesehatan}

DOI: $10.30994 /$ sjik.v9i2.372

ISSN: 2252-3847 (print); 2614-350X (online)

Vol.9 No.2 November 2020 Page.726-732

patients, using BPJS as insurance, completed medical record, financial data, medication, and claims. Real cost/hospital tariffs were collected through direct inspection to the hospital management consisting of cost component (hemodialysis cost, supportive medical procedure, blood service, laboratory examination, radiological examination, nursing, medication, disposable usage, and the other health tools. Meanwhile, INACBG's claims were examined in accordance to the Ministry of Health rules (PERMENKES) No.59 of 2014. All unit costs were analyzed in local currency (Rupiah).

\section{Data Analyses and Ethics}

Demographic characteristics, such as age, length of stay (days), hospital care class and comorbidities were analyzed in frequency distribution.To compare the cost difference between hospital tariff and INA CBG's, the study used Mann-Whitney test, because data was not normally distributed. Data was analyzed using SPSS (Statistical Package for Social Science). The ethical Ethical clearance was obtained from the Health Research Ethics Commission, Faculty of Medicine, Universitas Syiah Kuala, and Regional Hospital of Zainal Abidin with reference number: RSUDZA No.092 / EA / FKRSUDZA/ 2020 on June 19, 2020.

\section{RESULT}

It was demonstrated that the age mean of patients was 40-60 years old, which was more predominant for males with a percentage of 55.4\%. Most patients were treated in class 3 of hospitalization wards $(78.1 \%)$, with the average of $\leq 7$ days of treatment. Anemia, other unclassified diseases, and pulmonary edema became the most common comorbidities found among CKD patients in the study, consisting of 172, 116, and 49 patients, respectively. The general characteristics of patients enrolled in the study was detailed in Table 1. The result also shows that surgical procedure tariffs are the highest average costs among patients compared to the other groups of medical procedures or indicators (average cost for the surgical procedure was IDR 3,153,259) (Table 2). The average of INA-CBG tariff was IDR 8,227,100, and real costs/ hospital tariffs was IDR.10,373,186. Hospital tariff was higher than the INA-CBG's tariffs, with a gap difference of IDR 2,146,086. Statistically, there is a significant difference between INACBG rates and hospital rates in the care of patients with chronic kidney failure who had hemodialysis $(\mathrm{p}$-value $=0.014)($ Table 3$)$.

\section{DISCUSSION}

The study found that the average age of patients with CKD who performed hemodialysis at the installation in the period of January- December 2019 was 51.90 years of age. This clinical condition is associated with the attenuation of kidney function among elderly (Abdulkader et al., 2017). There is a progressive reduction in Glomerular Filtration Rate (GFR) and Renal Blood Flow (RBF), around $8 \mathrm{ml} / \mathrm{min} / 1.73 \mathrm{~m}^{2}$ per decade starting at the age of 40 years (Aisara et al., T.t.). Kasriani demonstrated that the 40-64 age groups as the most suffered population with CKD; there was a total of 53 patients $(60.2 \%)$ in the age of 40-64 years. Indonesia Renal Registry (IRR) 2017 also stated similar facts that the highest proportion of patients in the category of 45-64 years accounts for 59.15\% with CKD (IRR, 2018; Kasriani, 2016). In the gender aspects, male patients were still predominant among patients in the study, it included 225 male patients (55.4\%), while women with a total of 181 patients (46.6\%). The study by Roderick et al. (2011) in the United Kingdom discovered that the prevalence of CKD in the stage of 1-5 


\section{STRADA Jurnal Ilmiah Kesehatan}

DOI: $10.30994 /$ sjik.v9i2.372

ISSN: 2252-3847 (print); 2614-350X (online)

Vol.9 No.2 November 2020 Page.726-732

was $14 \%$ among male patients and $13 \%$ in women. Similarly, in the IRRs, CKDs have a similar pattern of patients, male patients were more dominant (57\%) than female patients (43\%) (IRR, 2018; Roderick et al., 2011).

The hospital care class of patients was mostly in third hospitalization wards, with a percentage of $78.1 \%$, and the average length of stay (days) was of 9.57 days of treatment. The national insurance company (BPJS), had the cheme where people with lower income will have the premi paid by the government, which is used to be called Aceh Health Insurance (JKA). This is the program is granted from the local government for providing a better in health services for the people of Aceh as part of universal health coverage. Aceh Health Insurance becomes the groundbreaking tools to provide universal health coverage in the region with financing system mimicking the BPJS system in which all Acehnese automatically stated as the Recipient of Assistance or 'Penerima Bantuan Iuran (PBI)' that previously regulated by the national rules in class 3 of treatment (PERGUB ACEH, 2018). All patients with premi paid by the government wntitiled for third class hospital care.

There were $66 \%$ of hemodialysis patients in the study had several comorbidities. It is stated in the theoretical background that various comorbidities will worsen the condition of hemodialysis patients and have an impact on accelerating mortality in the patient group (Utami et al., T.t.; McArthur et al., 2018). Anemia, other diseases, and pulmonary edema were the most common comorbidities in patients with chronic kidney failure. IRR was also mentioned that more than 87,000 patients with CKD have suffered from several complications of the CKD development per se; there were $78 \%$ patients with $\mathrm{Hb}<10 \mathrm{gr} / \mathrm{dl}$ and only $22 \%$ of patients with $\mathrm{Hb}>10 \mathrm{gr} / \mathrm{dl}$. In a recent study, Zadeh et al. also concluded that complication frequently occurs anemia among patients with chronic kidney failure. In another study, anemia was always accompanied by CKD patients (80-95\%) but not predominantly found among patients with chronic kidney failure due to polycystic kidney (Yulianto et al., 2017). Meanwhile, Pradesya's study demonstrated that there was a significant relationship between chronic kidney disease and pulmonary edema, with a percentage of $82.6 \%$ in 69 patients (Pradesya, t.t.). CKD patients have low immunity that tends to be more prone to infections such as pneumonia, urinary tract infection (UTI), and sepsis (Tecklenborg et al., 2018). This study found that 47 patients $(11.6 \%)$ had pneumonia. Bacterial pneumonia is a type of pneumonia that is more often experienced by patients with CKD. About $79 \%$ of CKD patients infected with pneumonia need to be hospitalized with a mortality of 33\% (Rosyid \& Thaha, t.t .; Viasus et al., 2011)

Additionally, some patients experienced hypertension and diabetes mellitus in this study, 48 and 28 patients, respectively. Nearly 30\% of CKD is caused by hypertension, and the prevalence of hypertension in newly diagnosed CKD is more than $85 \%$ (Aisara et al., T.t.). Maria et al. described comorbidities among CKD patients with hemodialysis patients in the Hemodialysis Unit of PKU Muhammadiyah Hospital, Yogyakarta, in which there were 69 patients $(87.3 \%)$ had hypertension, 59 patients $(74.7 \%)$ had diabetes mellitus. Diabetes mellitus is the cause of ESRD, as well as the common comorbidities of patients with ESRD (Shen et al., 2017). In this study, there were only seven patients (11.6\%) diagnosed with cardiovascular disease. This still needs attention because several studies explain the increasing morbidity and mortality rates in CKD patients was demonstrated mainly of patients with cardiovascular disease, including coronary heart disease. A study conducted by Goodkin that patients with chronic renal failure who have comorbid coronary heart disease have a significant relationship with the mortality among 


\section{STRADA Jurnal Ilmiah Kesehatan}

DOI: $10.30994 /$ sjik.v9i2.372

ISSN: 2252-3847 (print); 2614-350X (online)

Vol.9 No.2 November 2020 Page.726-732

CKD patients with hemodialysis (p-value <0,0001) (Goodkin, 2003). Conversely, patients without comorbidities of heart disease are likely to have a good quality of life, 2.770 times compared to patients with heart diseases (Utami et al., T.t.).

Unit cost for the care of CKD patients was discovered that with the highest mean of cost is the surgical procedure rate (IDR. 3,153,259). There was a wide variety of surgical procedure that has been conducted for the CKD patients in the hospital, one the most frequent procedure is vascular surgery (establishing fistula arteriovenous (FAV) or AV Shunt). The increasing number of new patients undergoing hemodialysis each year will also considerably raise the costs of vascular surgical procedures. Besides vascular access in patients with CKD, it is also possible that the patient experience many types of malignant complications, such as infection that is not very uncommon to repair the vascular access (Almasri et al., 2016). Based on the Mann Whitney test, it was found that the INA-CBG rate had an average of IDR. 8,227,100 and a real cots/ hospital tariff of Rp10,373,186. Hospital rates are greater than the INA-CBG rates with a difference in IDR. 2,146,086. Statistically, there is a significant difference between INA-CBG rates and hospital rates in the care of patients with chronic kidney failure ( $\mathrm{p}$-value $=0.014)$.

Kasriani et al. concluded that a significant or the biggest difference was in stage II of the severity level of IDR. 52,648,165 among class III of insurance groups. Azalea et al. mentioned that there were differences between hospital rates and INA-CBG's claims in some of the studies' disease groups. The considerable gap difference in hospital tariffs with INA-CBGs during September 2014 - August 2015 accounts for IDR. $225,632,939.96$ (29.47\% of total costs), which became the burden for hospital costs in the 47 episodes of hospitalization (Azalea, M., Andayani, T. M., \& Satibi., 2016; Kasriani, 2016). The occurrence of the discrepancy between real cost/hospital tariffs and INA-CBG's claim does not only occur in CKD patients undergoing hemodialysis. Lilissuriani et al. found a significant difference in the real cost of hospitals with INACBG's claim among coronary heart disease patients, as indicated by a p-value of 0.001 . The difference between hospital tariffs with INA-CBG is IDR.532,954,324 or $-27 \%$ of the INA-CBG's tariff. Prabowo et al. showed that there was a comparison of the real cost with INA-CBG rates for inpatients of IDR. 1,1408,100 and outpatients for IDR.-854,200 among hypertensive patients (Prabowo, Wisnu, 2018; Saputra, t.t.)

\section{CONCLUSIONS}

There is a difference between the real costs / hospital tariffs and INA-CBG's claim in CKD patients with hemodialysis at RSUDZA, in which real costs were greater than the INA-CBG's tariffs with an average difference of IDR. 2,146,086. The management of hospitals needs to conduct an evaluation and review of service standards and management of inpatient CKD patients with hemodialysis according to the case; thus, the cost discrepancy could be minimized preventing the financial risk for the hospital per se

\section{REFERENCE}

Abdulkader, R. C., Burdmann, E. A., Lebrao, M. L., Duarte, Y. A., \& Zanetta, D. M. (2017). Aging and decreased glomerular filtration rate: An elderly population-based study. PloS one, 12(12), e0189935.

Aisara, S., Azmi, S., \& Yanni, M. (t.t.). Gambaran Klinis Penderita Penyakit Ginjal Kronik yang Menjalani Hemodialisis di RSUP Dr. M. Djamil Padang. 


\section{STRADA Jurnal Ilmiah Kesehatan}

DOI: $10.30994 /$ sjik.v9i2.372

ISSN: 2252-3847 (print); 2614-350X (online)

Vol.9 No.2 November 2020 Page.726-732

Almasri, J., Alsawas, M., Mainou, M., Mustafa, R. A., Wang, Z., Woo, K., ... \& Murad, M. H. (2016). Outcomes of vascular access for hemodialysis: a systematic review and meta-analysis. Journal of vascular surgery, 64(1), 236-243.

Azalea, M., Andayani, T. M., \& Satibi. (2016). Analisis Biaya Pengobatan Penyakit Ginjal Kronis Rawat Inap Dengan Hemodialisis Di Rumah Sakit. Jurnal Manajemen dan Pelayanan Farmasi. Universitas Gajah Mada, 6(2), 141-150.

CNBC INDONESIA. (2019). https://www.cnbcindonesia.com/news/20190917195920-4100170/ngeri- penyakit-penyakit-ini-yang-buat-bpjs-kesehatan-tekor

Glassock, R. J., Warnock, D. G., \& Delanaye, P. (2017). The global burden of chronic kidney disease: estimates, variability and pitfalls. Nature Reviews Nephrology, 13(2), 104.

Goodkin, D. A. (2003). Association of Comorbid Conditions and Mortality in Hemodialysis Patients in Europe, Japan, and the United States: The Dialysis Outcomes and Practice Patterns Study (DOPPS). Journal of the American Society of Nephrology, 14(12), 3270-3277. https://doi.org/10.1097/01.ASN.0000100127.54107.57

Harnold, S. P., Zulfakar, \& Sovia, C. N. (2017). Analisis diskrepansi Tarif Rumah Sakit Dengan Tarif INA-CBG's Pada Pelayanan Rawat Inap di Rumah Sakit Umum Daerah dr. Zainoel Abidin Tahun 2017.

IRR. (2018). Indonesian Renal Registry. 46.

Kasriani. (2016). Analisa Biaya Terapi Gagal Ginjal Kronik Dengan Hemodialisis Pada Pasien Rawat Inap Di RSUD Pandan Arang. Setia Budi.

KEMENKES RI. (2010). Peraturan Menteri Kesehatan RI No 812 tahun 2010 Tentang Penyelenggaraan Pelayanan Dialisis Pada Fasilitas Pelayanan Kesehatan.

KEMENKES RI. (2016). Peraturan Menteri Kesehatan Republik Indonesia Nomor 76 Tahun 2016 tentang Pedoman Indonesian Case Base Groups (INA-CBG) dalam Pelaksanaan Jaminan Kesehatan Nasional.

McArthur, E., Bota, S. E., Sood, M. M., Nesrallah, G. E., Kim, S. J., Garg, A. X., \& Dixon, S. N. (2018). Comparing five comorbidity indices to predict mortality in chronic kidney disease: a retrospective cohort study. Canadian journal of kidney health and disease, 5, 2054358118805418

PERGUB ACEH. (2018). PERGUB ACEH NO 13 Tentang Jaminan Kesehatan Aceh.

Prabowo,Wisnu. (2018). Analisis Perbedaan Biaya Riil Rumah Sakit dengan Tarif INACBG's untuk Kasus Penyakit Hipertensi Primer Pada Pasien Era JKN. Islam Sultan Agung.

Pradesya, E. S. (t.t.). Hubungan Gagal Ginjal Kronik Dengan Edema Paru Ditinjau Dari Gambaran Radiologi. 9.

Presiden RI. (2011). Undang-undang Republik Indonesia Nomor 24 Tahun 2011 tentang Badan Penyelenggara Jaminan Sosial.

PUSDATIN. (2017). Situasi Penyakit Ginjal Kronis. KEMENKES RI.

Roderick, P., Roth, M., \& Mindell, J. (2011). Prevalence of chronic kidney disease in England: Findings from the 2009 Health Survey for England. Journal of Epidemiology \& Community Health, 65(Suppl 2), A12-A12. https://doi.org/10.1136/jech.2011.143586.26

Rosyid, A. N., \& Thaha, M. (t.t.). Tatalaksana Pneumonia Bakterial Pada Penyakit Ginjal Kronis. 14. 


\section{STRADA Jurnal Ilmiah Kesehatan}

DOI: $10.30994 / \mathrm{sjik} . v 9 i 2.372$

ISSN: 2252-3847 (print); 2614-350X (online)

Vol.9 No.2 November 2020 Page.726-732

Saputra, I. (t.t.). Perbedaan Biaya Riil Rumah Sakit Dan Tarif Ina-Cbg Untuk Kasus Katastropik Dengan Penyakit Jantung Koroner Pada Pasien Rawat Inap Peserta Jaminan Kesehatan Nasional Di Rsuza. 3(1), 8.

Shen, Y., Cai, R., Sun, J., Dong, X., Huang, R., Tian, S., \& Wang, S. (2017). Diabetes mellitus as a risk factor for incident chronic kidney disease and end-stage renal disease in women compared with men: a systematic review and meta-analysis.

Tecklenborg, J., Clayton, D., Siebert, S., \& Coley, S. M. (2018). The role of the immune system in kidney disease. Clinical \& Experimental Immunology, 192(2), 142-150.

Utami, M. P. S., Rosa, E. M., \& Khoiriyati, A. (t.t.). Gambaran Komorbid Pasien Hemodialisa. 6.

Viasus, D., Garcia-Vidal, C., Cruzado, J. M., Adamuz, J., Verdaguer, R., Manresa, F., Dorca, J., Gudiol, F., \& Carratala, J. (2011). Epidemiology, clinical features and outcomes of pneumonia in patients with chronic kidney disease. Nephrology Dialysis Transplantation, 26(9), 2899-2906. https://doi.org/10.1093/ndt/gfq798

Yulianto dkk. (2017). Analisis Ketahanan Hidup Pasien Penyakit Ginjal Kronis Dengan Hemodialisis Di Rsud Dr. Soetomo. 3(1), 99-112 